\title{
Evaluation of the sampling methods applied to phycoperiphyton studies in the Ratones River estuary, Brazil
}

\author{
Avaliação dos métodos de coleta aplicados no \\ estudo do ficoperifíton no estuário do rio Ratones, SC, Brasil
}

Bianca Vettorato ${ }^{1,3}$, Roselane Laudares-Silva $^{1}$, Dávia Talgatti $^{1}$ and Mariângela Menezes ${ }^{2}$

${ }^{1}$ Laboratório de Ficologia, Departamento de Botânica, Programa de Pós-Graduação em Biologia Vegetal, Centro de Ciências Biológicas, Universidade Federal de Santa Catarina, Campus Universitário Trindade, CP 476, CEP 88040-900, Florianópolis, SC, Brasil

e-mail: bivettora@gmail.com, rlsilva@ccb.ufsc.br, daviamt@gmail.com

${ }^{2}$ Laboratório de Ficologia, Quinta da Boa Vista, Universidade Federal do Rio de Janeiro, Museu Nacional, Horto-Botânico, São Cristóvão, CEP 20940-040, Rio de Janeiro, RJ, Brasil e-mail: menezesm@superig.com.br

\begin{abstract}
Aim: The present study aimed on testing the efficiency of four sampling methods for identification and quantification applied in studies on the biodiversity and spatial-temporal distribution of the phycoperiphyton in the Ratones River estuary; Methods: The sampling were carried out in three sampling stations along the Ratones River in March and August 2008. The methodologies used for the separation of the periphyton from the sediment were made with the use of sieves and trapping tissue. A removing method through manual agitation and "in situ" analysis was used for epiphytes. To evaluate the efficiency of the methodology for periphyton, data on phytoplankton was included for comparative reasons; Results: The trapping method option was the most appropriate for removing the live specimens from the sediment, and to try to minimize the problems found with the other two methodologies tested. In the case of the epiphytic microalgae the best counting technique resulted from the "in situ" method; Conclusions: In summary, the results presented here support the difficulties faced in studying phycoperiphytic samples in estuaries, which are shallow and dynamic environments, and for that reason the communities occurring in these areas are constantly influenced by the sediment.
\end{abstract}

Keywords: sampling methods, estuary, epipelic, epiphytic, phytoplancton.

Resumo: Objetivo: O presente trabalho tem por objetivo testar a eficiência de quatro métodos de coleta para a identificação e quantificação empregadas no estudo sobre a biodiversidade e distribuiçáo espaço temporal do ficoperifíton no estuário do rio Ratones; Métodos: As coletas foram realizadas em três estaçôes de amostragem ao longo do rio Ratones em março e agosto de 2008. As metodologias testadas para separação do perifíton do sedimento foram realizadas através do uso de peneiras e armadilhas de tecido. Para as epífitas, foi utilizado método de remoção através de agitação manual e análise "in situ". Para avaliar a eficiência da metodologia para perifíton, foram incluídos dados sobre fitoplâncton para fins comparativos; Resultados: A opção pelo método de armadilha mostrou ser mais adequada para separar os espécimes vivos, do sedimento, e para tentar minimizar os problemas encontrados nas outras duas metodologias testadas. No caso das microalgas epífitas, a melhor forma de análise resultou dos métodos "in situ"; Conclusóes: Em síntese, os resultados aqui apresentados reiteram as dificuldades encontradas ao se estudar amostras ficoperifíticas em ambientes estuarinos que, por serem ambientes rasos e dinâmicos, sofrem a influência constante do sedimento na formação das comunidades presentes nestes locais.

Palavras-chave: métodos de coleta, estuário, epipélica, epifítica, fitoplâncton. 


\section{Introduction}

Estuaries are transition ecosystems between river and sea. According to Pritchard (1967) it can be defined as a coastal water body semi-closed that has a link with open sea, and where the sea water gets mixed with the fresh water that comes from the continental shelf.

Due to the hydrodynamic characteristics that retain nutrients, algae and plants and stimulate the productivity of these water bodies, the estuaries are more productive then adjacent rivers and oceans (Miranda et al., 2002). A big difference between estuarine and other environments (marine and fresh water environments) is its higher dynamics that causes variations on the communities composition found there, in response to physical, geological, chemical and biological factors, characteristic of each place (Smayda, 1983; Sumich and Morrisey, 2004). The major influencing factors on the dynamics are: salinity, transparency, concentration and availability of organic nutrients (mainly nitrate, phosphate and silicate), dissolved $\mathrm{O}_{2}$ and $\mathrm{CO}_{2}$ concentration, light, temperature, $\mathrm{pH}$ and modifications on currents direction and velocity (Tundisi, 1970; Sartori and Nogueira, 1998).

Due to its relatively small size, the Ratones river drainage basin has a high marine influence mainly in the low and intermediate areas of the Ratones river, which is its main effluent. In this region occur the largest mangrove systems of the Santa Catarina Island, where it is partially protected since the Carijos Ecological Station was established, in 1986. The mangrove is located in a calm water region and is present along the Ratones river, surrounding its estuary. It is subjected to periodical floods, due to the wide tidal variations (Souza Sobrinho et al., 1969).

Phycoperiphyton and phytoplankton are the main primary producers in aquatic systems and due to their constantly carriage by the currents and water movements, these communities end up reflecting certain environmental characteristics (Tai and Hodgkiss, 1975). The phytoplankton composition and its dynamics in estuaries are also affected by environmental changes, accompanied by the fresh and salt water mixing, turbidity, dissolved organic matter and nutrients (Smayda, 1983).

The use of the benthos term was defended by Round (1971) to include the communities that live or have part of their life cycle associated to the sediment (mud, sand) or some type of surface (rocks, plants or artificial substrate). However, Sládecková (1962) points out that the original meaning of the benthos term is referred directly only to the organisms that live unattached from the substrate. Organisms that grow attached to any type of substrate are denominated "Aufwuchs", and periphyton is its most accepted term (Schwarzbold, 1990). Wetzel (1983) defines periphyton as a complex microbiota (bacteria, fungy, algae, protozoa and animals) community, organic and inorganic debris attached to a, live or dead, natural or artificial substrata. According to Round (1971), different denominations can be attributed depending on the type of substrata that these organisms are associated: epipelon (a community that grows on sediments); epiphyton (a community that grows attached or associated to other plants); epipsamon (a community that grows attached to sand grains) and epilython (a community that grows on rocky substrata). The communities that live free in the water and only spend relatively short periods of their life cycle in the sediment or associated to it would be classified as plankton or nekton. However, for Reynolds (1984) the term plankton refers to the communities adapted to drifting in the sea or in fresh water, which are subjected to a passive movement by the wind and currents.

The frequent sediment resuspension in estuaries promotes cyst and periphytic algae removal to the water column and they become part of the phytoplanctonic community (Baillie and Welsh, 1980; Laudares-Silva and Cimardi, 1989), playing an important role by transferring nutrients, debris and organisms to the water column (Shimeta and Sisson, 1999).

In a recent study, Poulíčková et al. (2008) distinguishes the types of periphyton, specially the epipelic ones, as well as pointing the importance to observe the contamination by the phytoplankton by cysts and colonizing cells.

Diferently from phytoplankton studies, the literature on phycoperiphyton, specially in respect to the methodology to be applied on these organisms study, is still very scarce (Bicudo 1990a, b).

The techniques and methodologies for identifying and counting periphyton (epiphyton, epipelon, epipsamon, epilython) have been approached by some authors in Brazil and the world (Round, 1960; Sládecková, 1962; Wetzel, 1964; Round and Palmer, 1966; Eaton and Moss, 1966; Round, 1971; Riznyck, 1973; Main and McIntire, 1974; Tai and Hodgkiss, 1975; Wetzel, 1983; Laudares-Silva and Cimardi, 1989; Schwarzbold, 1990; Bicudo 1990a, b; Stevenson, 
1996; Moschini-Carlos, 1999; Pompêo and Moschini-Carlos, 2003; Ribeiro et al., 2003; Matsuoka and Fukuyo, 2003; Foden et al., 2005; Poulíčková et al., 2008). Some of these works point out the still faced difficulties in setting the most precise way to perform the periphytic algae counting (Sládecková, 1962; Tai and Hodgkiss, 1975; Wetzel, 1983; Ribeiro et al., 2003).

The present study was planned to test for the efficiency of four identification and quantification sampling methods used in the spatial-temporal biodiversity and distribution of phycoperiphyton in the Rio Ratones estuary.

\section{Material and Methods}

Phycoperiphyton and phytoplankton sampling were carried out in three sampling stations along the Ratones River (Figure 1) in March (summer) and August (winter) 2008. For each period and sampling station samplings were made during the lowering and rising tides.

The term periphyton was adopted to describe the collection of all groups of bentonic microalgae. The terms epipelic and epiphytic were applied to identify the microalgae groups according to their physical localization.

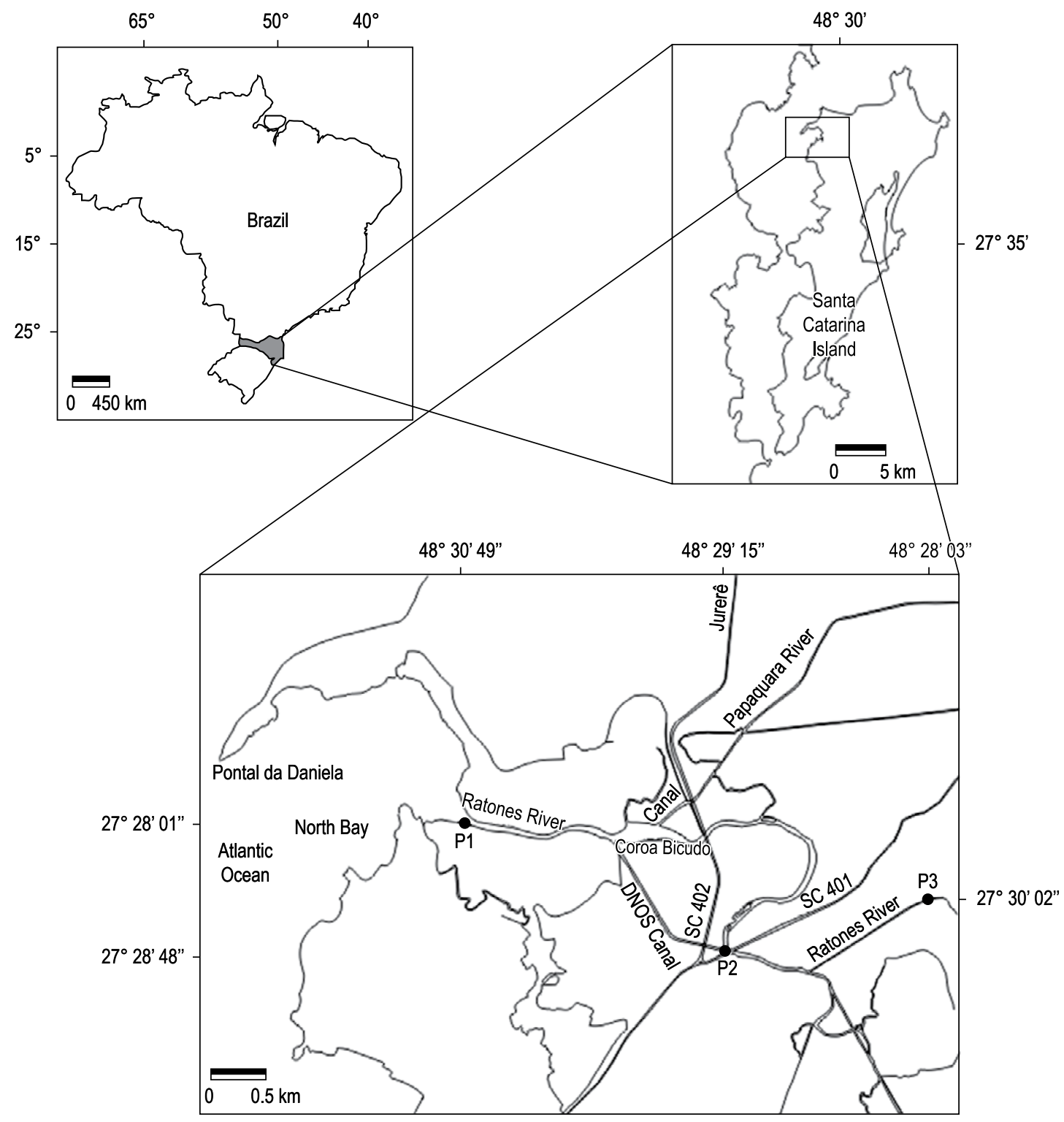

Figure 1. Ratones River and the three sampling stations (P1, P2, P3), Santa Catarina Island, Brazil. 
In order to evaluate the efficiency of the methodology for periphyton it was considered necessary the inclusion of the phytoplankton data for a better comparison and discussion of the results.

The qualitative study of the phytoplankton used $20 \mu \mathrm{m}$ mesh nets while for the quantitative study, surface water $(30 \mathrm{~cm})$ was sampled with $150 \mathrm{~mL}$ flasks. The qualitative samples were analyzed still alive. After that, a fraction was fixed with formalin $4 \%$ and another fraction was used for the diatoms material oxidation. The quantitative samples were fixed with acetic lugol at 1\% (Utermöhl, 1958, modified).

The epipelic algae were sampled from the sediment surface using a core $(10 \mathrm{~cm}$ in diameter by $2 \mathrm{~cm}$ in height). The epifitic algae were removed manually or with the help of a spatula from macroalgae which are substrate for different microalgae. The sediment and macroalgae samples were stored in plastic bags together with the same sampling station water.

Epiphytic organisms removal from the macroalgae followed Foden et al. (2005). The sampled macroalgae were kept in plastic bags with filtered (fibber glass $47 \mathrm{~mm}$ diameter) water from the same area of occurrence and collected together with the macroalgae sampled. The bags were manually shaken for 2 minutes to separate the epiphytic microalgae. After that, an epiphytic microalgae subsample was taken from the bags and fixed with acetic lugol $1 \%$ followed by identification and counting in inverse microscope. A macroalgae sample fraction was left untouched to check for the microalgae that were actually epiphytic. Only those fixed on the substrate, both on macroalgae and microalgae, were considered real epiphytes.

Initially, the sediment material analysis followed Matsuoka and Fukuyo (2003). A 1 mL sample from the surface sediment was placed in a Becker, diluted in filtered sea water, homogenized and then filtered using two sieves: the first of $80 \mu \mathrm{m}$ mesh and the second of $20 \mu \mathrm{m}$, from which a final suspension was obtained. The resulting $10 \mathrm{ml}$ volume was toped up with sea water. A subsample of this final volume was used both for the organisms quantification and identification.

A second method applied for obtaining the organisms present in the sediment was the "trapping method" (Eaton and Moss, 1966). The surface sediment volume obtained from the sampling sites was placed in Beckers and dark acclimated for at least 7 hours. Subsequently the supernatants were removed and the samples were homogenized and placed in Petri dishes. The dark acclimation process was made to avoid positive phototropism organisms discarding together with the removal of the supernatants. After transferring the sediment to Petri dishes, dual cellulose tissue quadrats $(2 \mathrm{~cm} \times$ $2 \mathrm{~cm}$ - Whatman 105) were placed on the top of the sample. The dishes were then covered and left for natural vertical illumination where no artificial light was applied at night. The quadrats were removed next morning at 9:00 and dissolved in $3 \mathrm{~mL}$ of acetic lugol and glycerol $4 \%$ for releasing the organisms that were attached to the tissue. This final volume was used both for the organisms quantification and identification. Only those captured by the cellulose tissue and that presented plastids were considered epipelic.

The organisms quantification were made in inverse microscope following Utermöhl (1958).

The cells were quantified in 100 random transects in inverse microscope LEITZ DIAVERT. Additional counting was made in SedwickRafter chambers in 100 random fields, only for phytoplankton, when the material presented very small flagellates which are hard to differentiate from the other organisms using Utermöhl.

Sub-samples of all the sampled material were kept without fixing, refrigerated, for fragile structures observation, movements, pigmentation and other characteristics which are commonly essential for identification. For the diatoms study, sub-samples were prepared according to Simonsen (1974) and the permanent microscope slides prepared with Naphrax to help on taxa identification.

\section{Results and Discussion}

As an estuarine environment, shallow and dynamic, that presents slimy soil with fine granulometry. All the samples presented a large amount of sediment, mainly silt and salt, which made it difficult to prepare the counting chambers, and sometimes, the observation in the microscope, requiring very often a high dilution of the samples.

Even the phytoplankton sample presented relatively high amount of suspended matter, however, its dilution was not necessary.

The high amount of sediment in the samples was the main reason for considering the application of Matsuoka and Fukuyo (2003) methodology inadequate for the study area. The excess of sediment present in the samples ended up curtaining the cells at the counting process. At least two dilutions 
were necessary for observing the cells still with difficulty. It caused material loss and exhausting counting, since the species visualization and consequent identification were compromised. It also caused lower results reliability, since the counting extrapolation was much higher.

Another problem was the presence of several algae without chloroplasts, which left doubts if they were really part of the studied substrata or had just been transported. Round (1971) discussed about the contamination problem caused by other algal associations and, in particular, by diatoms dead frustules. Ribeiro et al. (2003) also points out the difficulties in the sediment separation from the microalgae on their study.

The "trapping method" option was an alternative to separate the live specimens from the sediment and to try and minimize the problems found on the previous methodology. Another reason was the fact that this method is very efficient in identifying the really epipelic organisms, since it is based on the capture of organisms with positive phototaxy that move in the sediment layer when exposed to light. That way the non epipelic organisms, or those that are dead and only deposited in the sediment, are excluded. This method was very efficient, capturing not only diatoms, but other groups such as Cyanobacteria, Dinoflagellate, Chrysophyceae and Euglenophyceae. Besides that, it provided one of the cleanest samples for counting with inverse microscope. According to Laudares-Silva and Cimardi (1989), a deficiency of this method is the unknown migration rate of the studied communities. It could fail to capture some organisms during the removal of the cellulose tissue that retains the organisms. Round (1960), Round and Palmer (1966), Ribeiro et al. (2003), Poulíčková et al. (2008) have already applied the "trapping method" for all the algal groups, always highlighting the problem of the different species migration rates.

The methodology for epiphytes described by Foden et al. (2005) was totally inefficient for the studied environment. The microalgae were not completely unattached from the substrata, since several have tight mucilage or are incrusted on the substrata such as Xenococcus cf. schousbei Thuret, present in all macroalgae individuals sampled, but absent from the counting. Another problem was the excess of sediment on the macroalgae. While separating the epiphytes, the sediment ended up making part of the final suspension. Having the same granulometry as the microalgae, it was not possible to separate the sediment from the epiphytes. During the counting, the predomination of the epipelic species from the macroalgal sediment was more evident than the predomination of the epiphytic species.

Table 1 (attached) shows the Foden et al. (2005) methodology inefficiency for the quantification of the epiphytic microalgae, from which the high similarity (69\%) among the species found in the sediment and those obtained from the macroalgae suspension; and of these with the phytoplankton (58\%), can be observed. Only Melosira, Terpsinöe, Nitzschia brevissima Grunow, Komvophoron sp., Luticola ventricosa (Kützing) Mann and Achnantes sp. species were really the epiphytic ones found during the counting, and even though, in low numbers. Some cyanobacteria species that occurred in almost all the macroalgae samples, when observed "in situ" such as Xenococcus species, were underestimated, once they have not been found in any of the counting samples. In the case of the filamentous cyanobacteria Coleofasciculus chtonoplastes (Thur ex Gomont) Siegesmund et al. the result was inverse. This species occurs within a dense mucilage tube fixed on one extremity on the substrata and with the other open and unattached. As a result of the plastic bag shaken with the material to release the microalgae, the trichomes get out of the mucilage, become isolated, and can easily be confounded with some Phormidium species.

Besides that, several species known as non epiphytes, such as Euglena spp., Trachelomonas spp., Kephyrion ovale (Lackey) Huber-Pestalozzi, Bacillaria paxillifera (O. F. Müller) Hendey and Gyrosigma balticum (Ehrenberg) Rabenhorst, were also found in the counting. These results indicate with a high possibility that a large part of the counting obtained from the epiphytic algae samples correspond to those from the epipelic present in the sediment and that covered a significant fraction of the macroalgae.

Our study corroborates with Poulíčková et al. (2008), which pointed to the importance of observing the sediment contamination by phytoplanktonic organisms, considering the similarity among the species present in the sediment and in the phytoplankton in function of the influence of the resuspension of the sediment to the water column (as shown in Table 1).

In the case of the epiphytic microalgae the best counting method resulted from the "in 
Table 1. Microalgae taxa distribution according to the substrata where they were found and their sampling methodology.

\begin{tabular}{cccc}
\hline \multirow{2}{*}{ Taxa } & Epipelic & Epiphytic & Epiphytic ("in \\
& Phytoplanktonic & (Eaton and & (Foden et al., \\
Moss, 1966) & 2005) & situ") \\
\hline
\end{tabular}

\section{Cyanophyceae}

Anabaena sp.

Chroococcales

Chroococcus turgidus (Kützing) Nägeli

Coleofasciculus chtonoplastes Zanardini ex Gomont

Geitlerinema acutissimum (Kuffer.) Anag.

Geitlerinema amphibium (Agardh ex Gomont)

Anagnostidis

Geitlerinema spp.

Komvophoron constrictum (Szafer) Anag. et Komárek

Komvophoron sp. 1

Lyngbya aestuarii Liebman ex Gomont

Lyngbya sp.

Merismopedia convoluta Brébisson

Myxohyella sp.

Other Oscillatoriales

Phormidium retzii (Agardh) Gomont ex Gomont

Phormidium spp.

Planktolyngbya sp.

Pseudanabaena sp.

Spirulina major Kützing ex Gomont

Spirulina nordstedtti Gomont

$\begin{array}{cc} & \mathrm{x} \\ \mathrm{x} & \mathrm{x} \\ \mathrm{x} & \mathrm{x} \\ \mathrm{x} & \mathrm{x} \\ \mathrm{x} & \end{array}$

\section{$\mathrm{X}$}

$x$

$x$

$\mathrm{X}$

$x$

$x$

$x$

$\mathrm{X}$

$x$

$x$

$\mathrm{x}$

$\mathrm{x}$

$\mathrm{x}$

$x$

$x$

$x$

$x$

$x$

$x$

$x$

$x$

$x$

$\mathrm{X}$

$\mathrm{x}$

$x$

$\mathrm{x}$

$\mathrm{x}$

$\mathrm{x}$

$\mathrm{x}$

$x$

$x$

$x$

Xenococcus schousboei Thuret

Xenococcus pyriformis Setchell et Gardner

Xenotholos cf. starmachii (Geitler) Gold-Morgan et al.

\section{Euglenophyceae}

Euglena sp. 1

Euglena spp.

Euglenophyta

Eutreptiella eupharyngea Moestrup et Norris

Lepocinclis acus (O. F. Müller) Marin et Melkonian

Lepocinclis ovum (Ehrrnberg) Lemmermann

Lepocinclis oxyuris(Schmarda) Marin et Melkonian

Monomorphina pyrum (Ehr.) Mereschkowsky

Phacuscf. anomalus Fritsch et Rich

Phacus longicauda (Ehr.) Duj

Phacus spp.

Trachelomonas cf. abrupta Swirenko emend. Deflandre

Trachelomonas volvocinopsis Swirenko

Trachelomonas spp.

\section{Dinozoa}

Peridiniales 1

Peridiniales 2

Prorocentron sp.

\section{Chlorophyceae}

Chlamydomonas spp. 
Table 1. Continued...

\section{Taxa}

Phytoplanktonic

\section{Epipelic}

(Eaton and Moss, 1966)
Epiphytic

(Foden et al., Epiphytic ("in 2005)

Scenedesmus cf. acuminatus (Lagerheim) Chodat Scenedesmus spp.

\section{Cryptophyceae}

Cryptomonas sp.

\section{Chrysophyceae}

Kephyrion ovale (Lackey) Huber-Pestalozzi

\section{Coscinodiscophyceae}

Thalassiosira eccentrica (Ehrenberg) Cleve

Thalassiosira simonsene Hasle et Fryxell

Thalassiosira spp.

Cyclotella spp.

Melosira moniliformis (Müll.) Agardh

Melosira nummuloides (Dillw.) C. A. Agardh

Paralia sulcata (Ehrenberg) Cleve

Aulacoseira ambigua (Grunow) Simonsen

Actinoptychus sp.

Plagiogramma spp.

Terpsinoe americana (Bailey) Ralfs

Terpsinoe brebissoni (Kutzing) Van Heurck

Terpsinoe musica Ehrenberg

$\mathrm{X}$

$$
\text { X }
$$

$\mathrm{X}$

$X$

$\mathrm{X}$ $\mathrm{X}$

Terpsinoe sp. 1

Eucampia sp.

Eunotograma sp.

Dactyliosolen sp.

Leptocylindrus minimus Gran

$\mathrm{x}$

$x$

$x$

X

$\mathrm{X}$

$\mathrm{X}$

$x$

X

$\mathrm{X}$

$\mathrm{X}$

X

$\mathrm{X}$

$\mathrm{X}$

$\mathrm{X}$

$\mathrm{X}$

\section{Fragilariophyceae}

Raphoneis castracanei Grunow

Thalassionema frauenfeldii (Grunow) Hallegraeff

Thalassionema nitzschioide (Grunow) Van Heurck

Thalassionema sp.

\section{Bacillariophyceae}

Eunotia incisa Gregory

X

X

Lyrella sp.

Petroneis granulata (Bailey) Mann

Achnantes brevipes Agardh

Achnantes longipes Agardh

Achnantes sp.

Cosmioneis grossepunctata (Hustedt) Mann

Luticola inserata var. ondulata (Hustedt) Moser

Luticola ventricosa (Kützing) Mann

Fallacia sp.

Pinnularia spp.

Pinnularia yarrensis (Grunow) Juriej

Caloneis westii (Wm. Smith) Hendey

Diploneis cf. gruendleri (A. Schmidt) Cleve

Diploneis smithii (Brébisson) Cleve

Diploneis spp. 
Table 1. Continued...

\begin{tabular}{|c|c|c|c|c|}
\hline Taxa & Phytoplanktonic & $\begin{array}{c}\text { Epipelic } \\
\text { (Eaton and } \\
\text { Moss, 1966) }\end{array}$ & $\begin{array}{c}\text { Epiphytic } \\
\text { (Foden et al., } \\
2005) \\
\end{array}$ & $\begin{array}{l}\text { Epiphytic ("in } \\
\text { situ”) }\end{array}$ \\
\hline Diploneis weissflogii (A. Schmidt) Cleve & $\mathrm{x}$ & $\mathrm{x}$ & $\mathrm{x}$ & \\
\hline Navicula crucicula (Wm. Smith) Donkin & & $x$ & & \\
\hline Navicula cryptocephala Kützing & $x$ & $x$ & $x$ & \\
\hline Capartograma crucicula (Grunow ex Cleve) Ross & & $x$ & & \\
\hline Navicula spp. & $x$ & $x$ & $x$ & \\
\hline Naviculaceae & $x$ & $x$ & $x$ & \\
\hline Pleurosigma angulatum (Quekett) Wm. Smith & & $x$ & $x$ & \\
\hline Pleurosigma spp & $x$ & $x$ & & \\
\hline Gyrosigma acuminatum (Kützing) Rabenhorst & $x$ & $x$ & & \\
\hline Gyrosigma balticum (Ehrenberg) Rabenhorst & & $x$ & $x$ & \\
\hline Gyrosigma distortum (W. Smith) Griffith et Henfrey & & $x$ & & \\
\hline Gyrosigma cf. spectabile (Grunow ex Peragallo) Cleve & $x$ & & $\mathrm{x}$ & \\
\hline Gyrosigma fasciola (Ehrenberg) Griffith et Henfrey & $x$ & $x$ & & \\
\hline Gyrosigma sinense (Ehrenberg) Desikachary & & $x$ & & \\
\hline Gyrosigma sp. 1 & $x$ & $x$ & $x$ & \\
\hline Craticula riparia (Hustedt) Lange-Bertalot & & $x$ & & \\
\hline Amphora ovalis (Kützing) Kützing & $x$ & $x$ & $\mathrm{x}$ & \\
\hline Amphora spp. & $x$ & $x$ & $x$ & \\
\hline Bacillaria paxillifera (O. F. Müller) Hendey & $x$ & $x$ & $x$ & \\
\hline Tryblionella cf. acuminata W. Smith & $x$ & $x$ & $x$ & \\
\hline Tryblionella debilis Arnott & & $x$ & $x$ & \\
\hline Tryblionella granulata (Grunow) Mann & & $x$ & & \\
\hline Tryblionella punctata Wm. Smith & & $x$ & & \\
\hline Tryblionella sp. 1 & & & $x$ & \\
\hline Psammodictyon panduriforme (Gregory) Mann & $x$ & $x$ & & \\
\hline Nitzchia brevissima Grunow & & $x$ & $x$ & \\
\hline Nitzchia brittoni Hagelstein & & $x$ & $x$ & \\
\hline Nitzschia obtusa var. scallpeliformis Grunow & & $x$ & $x$ & \\
\hline Nitzschia pellucida Grunow & & $x$ & & \\
\hline Nitzschia reversa Wm. Smith & $x$ & $x$ & $x$ & \\
\hline Nitzschia sigma (Kützing) Wm. Smith & $x$ & $x$ & $x$ & $x$ \\
\hline Nitzschia spp. & $x$ & $x$ & $x$ & \\
\hline Nitzschia terrestris (Petersen) Hustedt & $x$ & $x$ & $x$ & $x$ \\
\hline Giffenia cocconeiformis (Grun.) Round & & $x$ & & \\
\hline Cylindrotheca closterium (Ehrenberg) Reimann et Lewin & $x$ & $x$ & & \\
\hline Cylindrotheca fusiformis Reimann et Lewin & $x$ & $x$ & & \\
\hline Rhopalodia sp. & & $x$ & & \\
\hline Entomoneis alata (Ehrenberg) Ehrenberg & $x$ & $x$ & & \\
\hline Entomoneis paludosa (W. Smith) Reimer & $x$ & $x$ & & \\
\hline Surirella sp. & $x$ & & & \\
\hline Other centric diatoms & $x$ & $x$ & $x$ & \\
\hline Other pennate diatoms & $x$ & $x$ & $x$ & \\
\hline Other phytoflagellates & $x$ & & & \\
\hline
\end{tabular}


situ" methods, described by Bicudo (1990b) and suggested in studies related to the subject (Sládecková, 1962; Wetzel, 1983). Despite this method have only been used for qualitative analysis in this study, we believe that this type of observation would allow an easy estimative of the number of individuals per $\mathrm{cm}^{2}$, which is contrary to the Foden et al. (2005) methodology applied in this study. One of the reasons why the Foden et al. (2005) methodology in not eficient is the fact that the substrata was represented by the following macroalgae species: Caloglossa cf. ogasawaraensis Okamura, Gayralia oxysperma (Kütz.) K. L. Vinogr. ex Scagel et al., Rhizoclonium tortuosum (Dillwyn) Kütz and Bostrychia calliptera (Montagne) Montagne, Bostrychia radicans (Montagne) Montagne and Bostrychia radicans f. moniliforme Post. These individuals are very small and delicate, which makes it difficult to remove the epiphytes from them by scraping. Besides that, due to their numerous branches, their area calculation would be over or underestimated. In the case of measuring by fresh or dry weight the Foden et al. (2005) methodology would also not be adequate due to the excess of sediment present on the macroalgae. This way, the "in situ" method would describe the area more precisely.

Finally, it is worth pointing out the difficulties and many times the impossibilities in identifying species in counting, mainly for diatoms, of which generic and specific taxonomic identities are only possible through electronic microscopy. In the case of diatoms and dinoflagellate the presence of chloroplasts frequently blocks the frustule structures and thecal plates visualization, which makes impossible to identify the material for counting. In very diverse environments and with absence of dominance of any species, as in this study, it also becomes very difficult to differentiate filamentous cyanobacteria, for example, when we know that in the same sample two very similar species can be present.

In summary, the results presented here support the difficulties faced in studying phycoperiphytic samples in estuaries, which are shallow and dynamic environments, and for that reason the communities occuring in these areas are constantly influenced by the sediment. Measures, such as the search for methods that eliminate most of the sediment without material losses, and a previous knowledge of the algae present in the studied environment are very important to guarantee a more reliable identification and quantification of the phycoperiphytic organisms.

\section{Acknoledgments}

The authors thank the Coordenação de Aperfeiçoamento de Pessoal de Nível Superior (CAPES) for the masters scholarships granted to the first and third authors.

\section{References}

BAILLIE, PM. and WELSH, P. 1980. The effect of tidal resuspension on the distribution of intertidal epipelic algae in a estuary. Estuarine and Coastal Marine Science, vol. 10, p. 165-180.

BICUDO, CEM. 1990a. Metodologia para o estudo qualitativo das algas do perifíton. Acta Limnologica Brasiliensia, vol. 3, p. 477-491.

BICUDO, DC. 1990b. Consideraçôes sobre metodologias de contagem de algas do perifíton. Acta Limnologica Brasiliensia, vol. 3, p. 459-475.

EATON, JW. and MOSS, B. The estimation of number and pigment content in epipelic algal populations. Limnology and Oceanography, 1966, vol. 11, p. 584-596.

FODEN, J., PURDIE, DA., MORRIS, S. and NASCIMENTO, SM. 2005. Epiphytic abundance and toxicity of Prorocentrum lima populations in the Fleet lagoon, UK. Harmful Algae, vol. 4, p. 1063-1074.

LAUDARES-SILVA, R. and CIMARDI, JM. 1989. Nota sobre a utilização do "Trapping Method" no estudo das diatomáceas epipélicas do manguezal de Ratones - Florianópolis - SC. Insula, vol. 19, p. 299-304.

MAIN, SP. and McINTIRE, CD. 1974. The distribution of epiphytic diatoms in Yaquina Estuary, Oregon (U.S.A). Botanica Marina, vol. 17, p. 88-99.

MATSUOKA, K. and FUKUYO, Y. 2003. Taxonomy of cysts. In: HALLEGRAEFF, GM., ANDERSON, DM. and CEMBELLA, AD., ed. Manual on Harmful Marine Microalgae. Paris: UNESCO. p. 563-592.

MIRANDA, LB., CASTRO, BM. and KJERFVE, B. 2002. Princípios de oceanografia física de estuários. São Paulo: Edusp. p. 414.

MOSCHINI-CARLOS, V. 1999. Importância, estrutura e dinâmica da comunidade perifítica nos ecossistemas aquáticos continentais. In POMPÊO, MLM., ed. Perspectivas na Limnologia do Brasil. São Luís: Gráfica e editora União. p. 198.

POMPÊ, MLM. and MOSCHINI-CARLOS, V. 2003. Macrófitas aquáticas e perifíton: aspectos ecológicos e metodológicos. São Carlos: RimaFAPESP. p. 130.

POULÍČKOVÁ, A., HAŠLER, P., LYSÁKOVÁ, M. and SPEARS, B. 2008. The ecology of freshwater epipelic algae: an update. Phycologia, vol. 47, no. 5, p. 437-450. 
PRITCHARD, DW. 1967. What is an estuary: physical viewpoint. In LAUFF, GH., ed. Estuaries. Washington, DC: American Association for the Advancement of Science Publication. vol. 83, p. 3-5.

REYNOLDS, CS. 1984. The ecology of freshwater phytoplankton. Cambridge: Cambridge University Press. p. 384.

RIBEIRO, L., BROTAS, V., MASCARELL, G. and COUTÉ, A. 2003. Taxonomic survey of the microphytobenthic communities of two Tagus estuary mudflats. Acta Oecologica, vol. 24, p. 117-123.

RIZNYK, RZ. 1973. Interstitial diatoms from two tidal flats in Yaquina Estuary, Oregon, USA. Botanica Marina, vol. 16, p. 113-138.

ROUND, FE. 1960. The diatom flora of salt marsh on the River Dee. New Phytologist, vol. 59, p. 332-348.

ROUND, FE. 1971. Benthic marine diatoms. Oceanography and Marine Biology: an annual review, vol. 9, p. 83-139.

ROUND, FE. and PALMER, JD. 1966. Persistent, vertical-migration rhythms in benthic microflora II. Field and laboratory studies on diatoms from the banks of the river avon. Journal of the Marine Biological Association of the UK, vol. 46, p. 191-214.

SARTORI, LP. and NOGUEIRA, MG. 1998. Estudo limnológico na regiáo estuarina dos rios Fazenda e Picinguaba, Parque Estadual da Serra do Mar (Ubatuba, SP), com ênfase na dinâmica dos nutrientes químicos. In Anais do IV Simpósio de Ecossistemas Brasileiros, 1998. São Paulo: Academia de Ciências do Estado de Sáo Paulo. vol. 1, p. 296-310.

SCHWARZBOLD, A. 1990. Métodos ecológicos aplicados ao estudo do perifíton. Acta Limnologica Brasiliensia, vol. 3, p. 545-592.

SHIMETA, J. and SISSON, JD. 1999. Taxon-specific tidal resuspension of protists into the subtidal benthic boundary layer of a coastal embayment. Marine Ecology Progress Series, vol. 177, p. 51-62.

SIMONSEN, R. 1974. The diatom plankton of the Indian Ocean Expedition of R/V "Meteor" 1964-1965. "Meteor" Forschungsergebnisse, vol. 19, p. 1-107.
SLÁDECKOVÁ, A. 1962. Limnological investigation methods for the periphyton ("Aufwuchs") community. Botanical Review, vol. 28, p. 286-350.

SMAYDA, TJ. 1983. The phytoplankton of estuaries. In KETCHUM, BH., ed. Estuaries and enclosed sea. Amsterdan: Elsevier Scientific Publishing. p. 65-102.

SOUZA SOBRINHO, RJ., BRESOLIN, A. and KLEIN, RPM. 1969. Os manguezais na Ilha de Santa Catarina. Insula, vol. 2, p. 1-21.

STEVENSON, RJ. 1996. An introduction to algal ecology in freshwater benthic habitats. In STEVENSON, JR., BOTHWELL, ML., LOWE, RL., ed.) Algal Ecology freshwater benthic ecosystems. Boston: Academic Press. 753 p. Aquatic Ecology Series.

SUMICH, JL. and MORRISSEY, JF. 2004. Introduction to the Biology of Marine Life. $8^{\text {th }}$ ed. Jones and Bartlett Publishers. p. 449.

TAI, YC. and HODGKISS, IJ. 1975. Studies on Plover Cove Reservoir, Hong Kong II. Seasonal changes in naturally occurring periphytic communities. Freshwater Biology, vol. 5, p. 85-103.

TUNDISI, JG. 1970. O plâncton estuarino. Contribuiçōes Instituto Oceanográfico da Universidade de São Paulo, vol. 19, p. 1-22.

UTERMÖHL, H. 1958. Zur Vervollkommung der quantitativen phytoplankton-methodik. Mitteilung Internationale Vereinigung für Theoretiche und Angewandte Limnologie, vol. 9, p. 1-38.

WETZEL, RG. 1964. A comparative study of the primary productivity of higher aquatic plants, periphyton, and phytoplankton in a large, shallow lake. International Revue ges. Hydrobiologie, vol. 49, no. 1, p. 1-61.

WETZEL, RG. 1983. Recommendations for future research on periphyton. In WETZEL, RG., ed. Periphyton of freshwater ecosystems. The Hague: Dr. W. Junk Publishers. p. 339-346.

Received: 24 May 2010 Accepted: 01 October 2010 